ORIGINAL RESEARCH PAPER

Presented at the $10^{\text {th }}$ International Symposium EuroAliment 2021

\title{
QUALITY CHARACTERISTICS OF WHITE BRINED CHEESE PRODUCED FROM GOAT MILK WITH DIFFERENT SOMATIC CELL COUNT
}

\author{
TATYANA BALABANOVA, MIHAELA IVANOVA* \\ University of Food Technologies, 26 Maritsa Blvd., 4002 Plovdiv, Bulgaria \\ "corresponding author: mivanova@uft-plovdiv.bg
}

Received on 24 May 2021

Revised on 27 July 2021

\begin{abstract}
This experimental work aimed to investigate the quality characteristics of white brined cheese during ripening, produced from goat milk with different somatic cell count: I group - with low somatic cell content (CL) with about 1200000 cells/ml; II group - with high somatic cell content $(\mathrm{CH})$ with about $1750000 \mathrm{cells} / \mathrm{ml}$ and III group - with medium somatic cell content (CM) with about $1600000 \mathrm{cell} / \mathrm{ml}(\mathrm{CM})$. Chemical, microbiological, and sensorial evaluations were performed on the $1^{\text {st }}$ and $45^{\text {th }}$ day of cheese ripening. The obtained results showed that the differences in the composition of goat milk during the different stages of lactation as well as the level of somatic cell count had a significant effect $(\mathrm{p}<0.05)$ on the chemical composition of the cheese samples. It was established that the total lactic acid bacteria count in the experimental samples decreased from 8.2 to $7.9 \log \mathrm{cfu} / \mathrm{g}$ for $\mathrm{CL}$ and $\mathrm{CM}$ and to 7.5 $\log \mathrm{cfu} / \mathrm{g}$ for $\mathrm{CH}$ at the end of the ripening period respectively. It was found that the psychrotrophic microorganisms and total yeast and molds decreased during the ripening period. The sensorial evaluation demonstrated a higher score for CL and CM samples in comparison with the $\mathrm{CH}$ sample.
\end{abstract}

Keywords: quality, ripening, somatic cell count, white brined cheese

\section{Introduction}

The dairy industry is the most important agricultural sector in Bulgaria. For the dairy industry, the white brined cheese is a main national dairy product with old and long traditions. After cow milk, sheep and goat milk are the basic raw materials used in the production of high-quality dairy products (Da Silva and Da Costa, 2019). The quality of raw milk is determined by its chemical composition and its sanitary and hygienic characteristics (Sharma et al., 2011; Petzer et al.,

https://doi.org/10.35219/foodtechnology.2021.2.01 
2017). The chemical composition of milk determines its nutritional value, technological properties, and cheese yield. The sanitary and hygienic condition of milk is determined by two main characteristics: total bacterial count (TBC) and somatic cell count (SCC). The high content of the total bacterial count in milk (over $100000 \mathrm{cfu} / \mathrm{ml}$ for cows and over $1500000 \mathrm{cfu} / \mathrm{ml}$ for sheep and goats), according to Regulation (EC) No 853/2004, poses a potential risk to the health of consumers and deteriorates the technological qualities of milk. The presence of a high somatic cell count in milk is an indicator of inflammation of the mammary gland (mastitis). According to a number of authors, the indicator somatic cell count (SCC) is widely used to assess the quality and suitability of milk (Sharma et al., 2011; Hunt et al. 2013).

Goat milk has many essential components, especially proteins with high biological quality, nutritional and functional properties and is a good source of vitamins, minerals like calcium, phosphorus, riboflavin, and medium-chain fatty acids (Bergillos-Meca et al., 2015; Clark and García, 2017; Verruck et al., 2019). Goat milk with different SCC load was explored in order to determine its influence on product quality (Balabanova and Ivanova, 2021). Further research about white brined cheese quality according to the somatic cell count of the used goat milk has to be made.

Therefore, the aim of the present work was to investigate the quality characteristics of white brined cheese, produced from goat milk with different levels of somatic cell count.

\section{Materials and methods}

Goat milk was delivered at different times of the year (May, August, and November) from Plovdiv 1 Farm, Orizare village, Plovdiv region, Bulgaria and met the requirements of Regulation 853/2004. The analysis of the chemical composition of the milk (milk fat, milk protein, solids and lactose, as well as dry matter (water content, respectively), solid-non-fat, freezing point, density, proteins, lactose, minerals), titratable and active acidity, absence of antibiotics, as well as its microbiological characteristics (total bacterial count - TBC - and somatic cell count - SCC), were already published (Balabanova and Ivanova, 2021) (Table 1).

On the basis of somatic cell count values, goat milk samples were categorized into three groups: CL - white brined cheese produced from goat milk containing about 1 $200000 \mathrm{cell} / \mathrm{ml} \mathrm{SCC}$; CM - white brined cheese produced from III group goat milk containing $1600000 \mathrm{cell} / \mathrm{ml} \mathrm{SCC}$; $\mathrm{CH}$ - white brined cheese produced from II group goat milk containing about $1750000 \mathrm{cell} / \mathrm{ml} \mathrm{SCC}$.

White brined cheese, from the three groups, was produced applying a classic production technology (Edgaryan and Panayotov, 2011). The milk was clarified (at 35 to $45^{\circ} \mathrm{C}$ ), pasteurized (at 68 to $70^{\circ} \mathrm{C}$ for $10-15 \mathrm{~min}$ ), cooled (at 32 to $34^{\circ} \mathrm{C}$ ) and inoculated with a starter culture containing Lactobacillus delbrueckii ssp. bulgaricus, Streptococcus thermophilus, Lactobacillus casei, Lactococcus lactis ssp. lactis in the amount of $0.15 \%$. 
Table 1. Chemical and microbiological composition of raw goat milk.

\begin{tabular}{|c|c|c|c|}
\hline \multirow{2}{*}{ Properties $^{1}$} & \multicolumn{3}{|c|}{ Goat milk } \\
\hline & May & August & November \\
\hline Dry matter, $\%$ & $12.75 \pm 0.34^{\mathrm{a}}$ & $12.00 \pm 0.25^{\mathrm{b}}$ & $12.63 \pm 0.30^{\mathrm{a}}$ \\
\hline Solid non-fat, $\%$ & $8.80 \pm 0.10^{\mathrm{a}}$ & $8.50 \pm 0.04^{\mathrm{b}}$ & $8.60 \pm 0.05^{\mathrm{a}}$ \\
\hline Milk fat, $\%$ & $3.95 \pm 0.05^{\mathrm{a}}$ & $3.50 \pm 0.06^{\mathrm{b}}$ & $3.90 \pm 0.05^{\mathrm{a}}$ \\
\hline Proteins, $\%$ & $3.40 \pm 0.10^{\mathrm{a}}$ & $3.20 \pm 0.11^{\mathrm{a}}$ & $3.30 \pm 0.10^{\mathrm{a}}$ \\
\hline Lactose, $\%$ & $4.60 \pm 0.10^{\mathrm{a}}$ & $4.45 \pm 0.04^{\mathrm{b}}$ & $4.60 \pm 0.08^{\mathrm{a}}$ \\
\hline Minerals, $\%$ & $0.80 \pm 0.01^{\mathrm{a}}$ & $0.80 \pm 0.02^{\mathrm{a}}$ & $0.80 \pm 0.01^{\mathrm{a}}$ \\
\hline Density, $\mathrm{g} / \mathrm{cm}^{3}$ & $1.029 \pm 0.002^{\mathrm{a}}$ & $1.029 \pm 0.001^{\mathrm{a}}$ & $1.028 \pm 0.001^{\mathrm{a}}$ \\
\hline Freezing Point, ${ }^{\circ} \mathrm{C}$ & $-0.570 \pm 0.001^{\mathrm{a}}$ & $-0.567 \pm 0.001^{b}$ & $-0.569 \pm 0.001^{\mathrm{a}}$ \\
\hline Titratable acidity, ${ }^{\circ} \mathrm{T}$ & $18 \pm 1^{\mathrm{a}}$ & $17 \pm 2^{\mathrm{a}}$ & $17 \pm 1^{\mathrm{a}}$ \\
\hline $\mathrm{pH}$ & $6.78 \pm 0.03^{\mathrm{a}}$ & $6.72 \pm 0.03^{\mathrm{a}}$ & $6.76 \pm 0.01^{\mathrm{a}}$ \\
\hline $\begin{array}{l}\text { Test for detection of } \\
\text { antibiotics and } \\
\text { inhibitors }\end{array}$ & Negative & Negative & Negative \\
\hline $\mathrm{TBC}, \mathrm{cfu} / \mathrm{ml}$ & $6.8 \times 10^{5} \pm 250^{\mathrm{a}}$ & $9.1 \times 10^{5} \pm 320^{b}$ & $7.4 \times 10^{5} \pm 300^{c}$ \\
\hline $\mathrm{SCC}$, cell/ml & $1200000 \pm 1440^{\mathrm{a}}$ & $1750000 \pm 1750^{\mathrm{b}}$ & $1600000 \pm 1600^{c}$ \\
\hline
\end{tabular}

A $30 \mathrm{~mL}$ portion of calcium dichloride solution (50\%) (previously diluted in water in 1:10 ratio) per $100 \mathrm{~L}$ of milk and rennet (previously diluted in water in 1:10 ratio) were added in such amount that the coagulation started 7 to 9 min after the enzyme addition and the complete coagulation took place after 40 to $60 \mathrm{~min}$. A coagulum set was formed and the curd was cut vertically and horizontally in cubes of 2 or $3 \mathrm{~cm}$ in size and left to stand for 10 to $15 \mathrm{~min}$. The curd was stirred 2 or 3 times at intervals of 10 to $15 \mathrm{~min}$. The polyethylene layer was separated, the curd was de-wheyed and a cheese block was formed. It was self-pressed for $10 \mathrm{~min}$, shaped by untying and breaking 2 to 3 times in 10 to $15 \mathrm{~min}$ intervals and a final shaping and pressing took place in order to assure the height of the cheese block of $10 \mathrm{~cm}$, length and width multiples of $10 \mathrm{~cm}$. The first $(40 \mathrm{~kg}$ per total cheese block) and second ( $80 \mathrm{~kg}$ per total cheese block) pressing were realized. The cheese block was further cut into smaller pieces of $120 \times 120 \mathrm{~cm}$ when the water content of the fresh cheese achieved $62 \%$ and titratable acidity of 50 to $80^{\circ} \mathrm{Th}$. Salting in brine was carried out at the following parameters: salt in brine concentration -20 to $22 \%$, titratable acidity - up to $25^{\circ} \mathrm{Th}$, brine temperature -14 to $15{ }^{\circ} \mathrm{C}$, time for brining 14 to $16 \mathrm{~h}$. During this stage, the white brined cheese achieved a $2.2 \%$ salt content. The cheese was arranged in metal boxes and further dry salted with $200 \mathrm{~g}$ of salt equally distributed between four layers of cheese. The preliminary cheese ripening took place at 15 to $18^{\circ} \mathrm{C}$ for $48 \mathrm{~h}$ until the titratable acidity reached 180 to $200{ }^{\circ} \mathrm{Th}$. A brine solution ( 8 to $10 \%$ salt content and titratable acidity 150 to $180^{\circ} \mathrm{Th}$ ) was added to the boxes which were further 
hermetically closed. The cheese ripened (at 8 to $10^{\circ} \mathrm{C}$ and relative humidity 70 $75 \%$ ) for 45 days.

Cheese samples were analyzed on the $1^{\text {st }}$ and $45^{\text {th }}$ day of ripening for the following chemical parameters: fat content according to Gerber-Van Gulik method (BS 167189); Dry matter and water content according to (BS 1109-89); Sodium chloride content according to BS 8274-82; Determination of total nitrogen content by Kjeldahl method (BS EN ISO 8968-1:2001); Titratable acidity by the Thorner's method (BS 1111-80) and potentiometric $\mathrm{pH}$ measurement.

Cheese samples were evaluated by the following microbiological parameters Total lactic acid bacteria count according to the IDF Standard 117B (1997); Determination and enumeration of psychrotrophic microorganisms (BS ISO 17410:2019); Total yeast and mould (BS EN ISO 6611:2006); Coliforms (ISO 4831:2006); L. monocytogenes (BS EN ISO 11290-1:2017); Coagulase-positive Staphylococci (BS EN ISO 6888-1:2005).

The sensorial evaluation of the cheese samples was carried out according to BNS 15612:83.

Statistical analysis was performed with computer processing of the results using the program Microsoft Excel 2010 (ANOVA). The results are presented as mean value $\pm \operatorname{SD}(n=12)$. The results were considered statistically different when $\mathrm{p}<0.05$.

\section{Results and discussion}

Table 2 presents the results of the physicochemical analysis of cheese samples on the first and last day of the ripening process. The results showed that the differences in the composition of the goat milk (Table 1) during the different stages of lactation had a significant impact on the composition of the cheese and the processes activity that took place during the ripening period.

A constant decreasing tendency in the values of $\mathrm{pH}$ was established during the process of ripening in the samples $\mathrm{CL}, \mathrm{CM}$, and $\mathrm{CH}$. A more active lactic acid process and an increase in titratable acidity were reported in CL and CM samples and less acidification for $\mathrm{CH}$. The established trend was directly dependent on the buffer capacity, e.g. the oxidation reduction potential in the system and the change of some components (proteins and lactose) under the action of the lactic acid bacteria (Figure 1).

Vianna et al. (2008) reported that milk with higher SCC results in the increase of $\mathrm{pH}$ in cheese samples, while another author (Bangieva, 2019) found that $\mathrm{pH}$ decreases at the end of the ripening period. At the beginning of the ripening process the salt content in the cheese was $3.2 \pm 0.1 \%$ and by the end of the studied period the salt content increased to about $3.5 \%$. The dynamics of the salting process in the experimental samples were closely dependent on the structure of the cheese and its water content. 


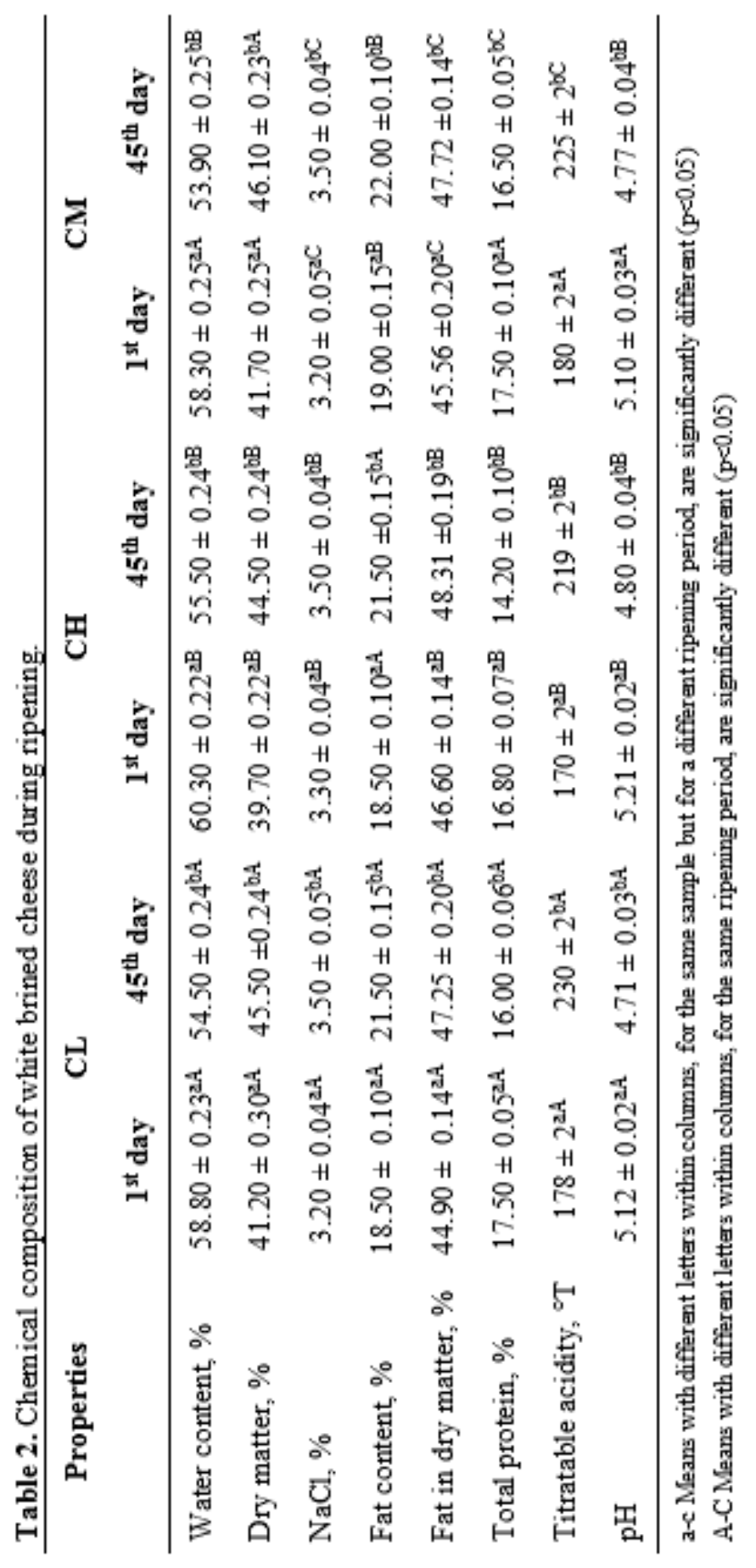


The active diffusion processes in these samples created a condition for relatively fast equalization of the salt content in the different layers of the cheese. While in the studies of Sulejmani and Hayaloglu (2017) that indicator in fresh cheese was in the range of $2.02 \div 2.73 \%$, the observed data from Barac et al. (2017) for the salt content in white brined goat's milk cheese for the period $10^{\text {th }}$ to $50^{\text {th }}$ day of production were significantly lower $-1.85 \div 2.10 \%$. This change was due to the different values of the characteristics dry matter, water content, brine concentration, and acidification, as well as the applied specific technology. It was established that the values of the dry matter indicator increased along with the gradual decrease of the water content in the cheese. The average value of that indicator was in accordance with the results obtained from Bojanić Rašović et al. (2010). The total protein in the system decreased during the studied period due to the proteolysis of the protein molecule. The values of the fat content in the total mass of the three cheese samples changed compared to the change in the dry matter content. Our results were consistent with the results of (Dimitrova et al., 2020), which indicated that fat contents in cow cheese ranged between $21-27 \%$.

Figure 1 shows the dynamics in the development of the total lactic acid bacteria count during ripening of the studied samples of white brined cheese from goat's milk. The results showed that at the beginning of the ripening process in the two experimental samples goat milk cheese was approximately $8.1 \mathrm{log}$ units. These values indicated the good development of starter lactic acid bacteria in the previous stages of the technological process. A slightly higher total lactic acid bacteria count was found in $\mathrm{CL}$ which was a piece of evidence for a more intensive development during the pre-ripening period and correlated with the higher reported values for the water content indicator. In all analyzed samples there was an increase in the amount of lactic acid bacteria count during the first 15 days of ripening.

The conducted research established the clear influence of SCC on the ripening process and at the same time, the development of the lactic acid bacteria count. From the $15^{\text {th }}$ to the $30^{\text {th }}$ day in samples CL and CM there were insignificant changes $(p>0.05)$ in the lactic acid bacteria count, which corresponded to the stationary phase of its development. A more significant reduction $(\mathrm{p}<0.05)$ in lactic acid bacteria count was established between the 15th and 30th day after the ripening of the $\mathrm{CH}$ samples. After that period until the end of ripening, the trend changed and a constant process of reduction of lactic acid biomass was observed and at the end of the process has reached values from $7.9 \log \mathrm{cfu} / \mathrm{g}$ (CL and $\mathrm{CM}$ ) to $7.5 \log (\mathrm{CH})$. These results were similar to the results obtained at the end of the ripening period for Macedonian traditional white brined cheese (Sandra et al., 2013) where the mean lactic acid bacteria content was $7.0 \mathrm{log} \mathrm{cfu} / \mathrm{g}$. 


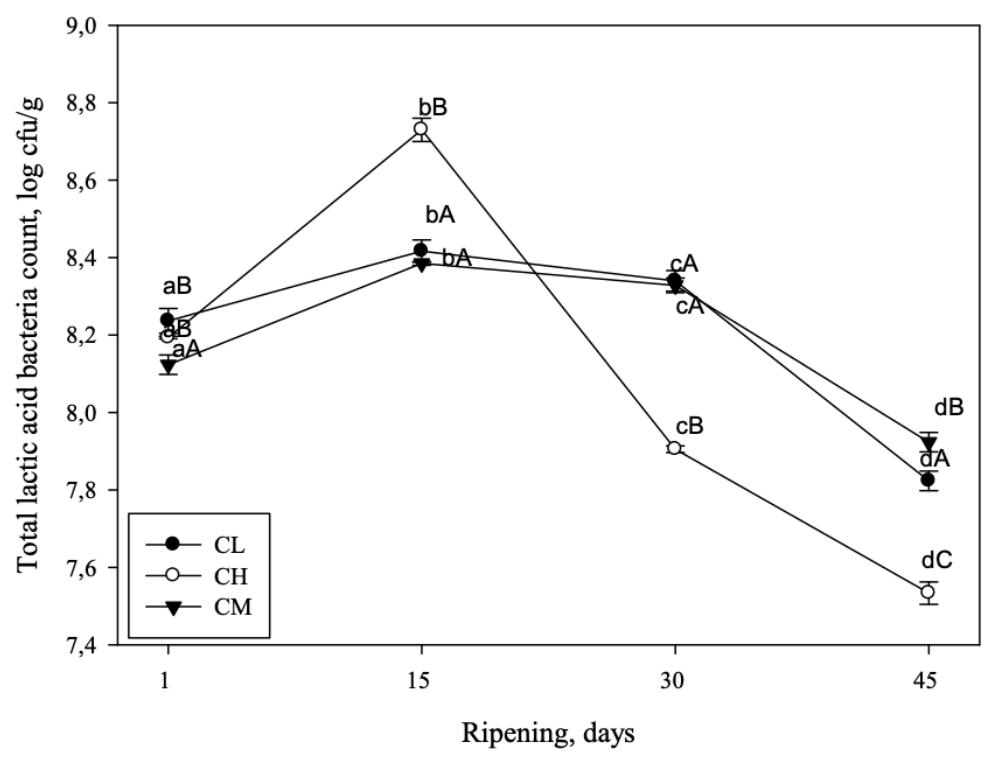

Figure 1. Change of total lactic acid bacteria count in white brined cheese from goat's milk during ripening. ${ }^{a-d}$ Means with different letters within a range are significantly different $(p<0.05)$; A-C Means with different letters within different series are significantly different $(p<0.05)$.

The results regarding the change of the nonstarter microflora in samples of white brined goat milk cheese during the ripening process are presented in Table 3 . The low levels of nonstarter microflora in the samples were a result of the good hygienic conditions in the production process, as well as the correct conduct of the technological operations.

Table 3. Survival of nonstarter microflora in white brined cheese from goat's milk during ripening.

\begin{tabular}{|c|c|c|c|c|c|c|}
\hline \multirow{2}{*}{$\begin{array}{c}\text { Nonstarter } \\
\text { microflora, } \\
\text { cfu/g }\end{array}$} & \multicolumn{2}{|c|}{ CL } & \multicolumn{2}{|c|}{$\mathbf{C H}$} & \multicolumn{2}{|c|}{$\mathbf{C M}$} \\
\hline & $1^{\text {st }}$ day & $45^{\text {th }}$ day & $1^{\text {st day }}$ & $45^{\text {th }}$ day & $1^{\text {st }}$ day & $45^{\text {th }}$ day \\
\hline Psychrotrophic & $\begin{array}{l}1.2 \times 10^{3} \\
+01 \mathrm{aA}\end{array}$ & $\begin{array}{l}1.3 \times 10^{2} \\
+01 \mathrm{bA}\end{array}$ & $1.1 \times 10^{3} \pm$ & $1.2 \times 10^{2} \pm$ & $\begin{array}{l}1.0 \times 10^{3} \\
+02 \mathrm{aC}\end{array}$ & $1.1 \times 10^{2} \pm$ \\
\hline $\begin{array}{l}\text { microorganisms } \\
\text { Yeast and mold }\end{array}$ & $\begin{array}{c} \pm 0.1^{\mathrm{a} A} \\
<100\end{array}$ & $\begin{array}{c} \pm 0.1^{\mathrm{OA}} \\
\mathrm{ND}\end{array}$ & $\begin{array}{l}0.2^{\mathrm{aD}} \\
<100\end{array}$ & ND & $\begin{array}{c} \pm 0.2^{2 u} \\
<100\end{array}$ & $\begin{array}{l}0.1^{\circ} \\
<10\end{array}$ \\
\hline Coliforms & ND & ND & ND & ND & ND & ND \\
\hline $\begin{array}{l}\text { Listeria } \\
\text { monocytogenes }\end{array}$ & ND & ND & ND & ND & ND & ND \\
\hline $\begin{array}{l}\text { Coagulase- } \\
\text { positive } \\
\text { staphylococci }\end{array}$ & ND & ND & ND & ND & ND & ND \\
\hline
\end{tabular}


Psychrotrophic microorganisms can get into the cheese at any stage of production, from technological equipment and can contaminate the finished product. The contamination of the tested samples with psychrotrophic microorganisms at the beginning of the ripening process was low and varied between 1.0 and $1.2 \times 10^{3}$ $\mathrm{cfu} / \mathrm{g}$. The normal development of the lactic acid bacteria count during the ripening process was accompanied by an increase in acidity and inhibited the development of the psychrotrophic microflora. The viability of yeast in white brined cheese depends on many factors - composition of milk, nutrients availability, interactions with co-existing microorganisms, production, storage conditions and etc. (Soliman Neveen and Salwa, 2011; Buehler et al., 2017; Lacanin et al., 2017).

It was established that the yeast and mould count decreased during the ripening period which correlated with the increase in acidity. In a contrast with our results, Šuranská et al. (2016) established that the total yeast counts in Serbian artisanal white-brined cheese increased during the ripening period between the $1^{\text {st }}$ to $10^{\text {th }}$ day (from $10^{4}$ to $10^{6} \mathrm{cfu} / \mathrm{g}$ ).

According to Chipilev et al. (2016), which analyzed white brined cheeses from Bulgarian dairies, produced with heat treated cow milk and vacuum packaged after a ripening period of 45 days, concluded that more than $63 \%$ of cheese samples were contaminated with yeast in total counts of $10^{2}$ to $10^{6} \mathrm{cfu} / \mathrm{g}$. The present study did not detect the presence of coliform bacteria, coagulase-positive staphylococci, and listeria monocytogenesis. Our results correspond with the results obtained from Kalevska et al. (2017). These results comply with the regulations on special demands for microbiological criteria for food.

The results of the sensorial evaluation of the tested samples of white brined goat milk cheese at the end of the ripening process are presented in Figure 2.

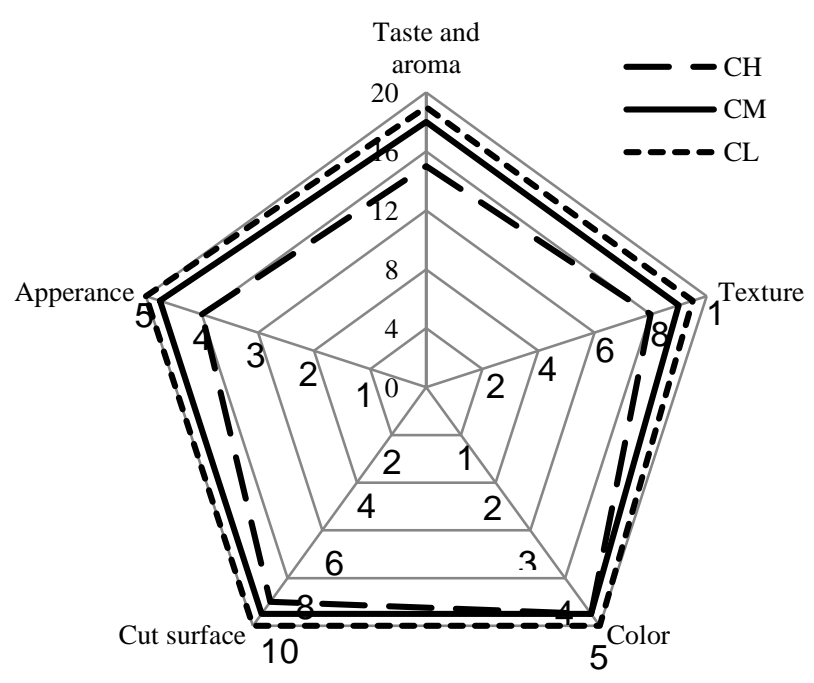

Figure 2. Sensorial evaluation of white brined cheese from goat milk during ripening. 
The obtained data showed that the samples CL and CM had better taste-aromatic properties, specific for the respective type of cheese, whereas the samples $\mathrm{CH}$ were characterized by a lower sensorial evaluation. The three batches of cheese had a typical appearance - good shape of the individual pieces, correct square base, and standard sizes.

The CL and CM cheese samples were characterized by a moderately hard and elastic consistency, a smooth cut surface with a visible gloss of the fracture, without layering, and uniform white color. $\mathrm{CH}$ cheese samples had a slightly elastic and slightly greasy consistency. This is probably due to lower established acidity values and higher water content. According to Chen et al. (2010) high SCC (1 $000000 \mathrm{cell} / \mathrm{ml}<\mathrm{SCC}<1500000 \mathrm{cell} / \mathrm{ml})$ in goat milk seems to affect the sensory characteristics and quality of matured cheeses.

\section{Conclusions}

The occurrence of bacterial infection in dairy animals led to a number of adverse changes in the composition and properties of milk and the quality of the finished product. The production of white brined cheese from goat milk, containing a high somatic cell count, was characterized by altered chemical composition and sensorial profile. The conducted research established a clear influence of SCC on the dynamic of the ripening process and at the same time, faster development of the lactic acid bacteria count. Therefore, the use of milk with high values of SCC resulted in different quality characteristics of white brined cheese compared to milk with low and medium SCC.

\section{Acknowledgments}

This study was carried out with the financial support of the Scientific Investigation Section Project 03/20-H, Science Fund, University of Food Technologies, Plovdiv, Bulgaria.

\section{References}

Balabanova, T., Ivanova, M. 2021. Relationship between somatic cell count in goat milk and mature Kashkaval cheese parameters. Agronomy research, 19(2), 357-368.

Bangieva, D. 2019. Microbiological and physicochemical changes during ripening in Bulgarian white brined cheese made from raw caw milk. Bulgarian Journal of Veterinary Medicine, 23(4), 494-503.

Barac, M., Pešić, M., Vucic, T., Tanja, Vasić, M., Smiljanić, M. 2017. White cheeses as a potential source of bioactive peptides. Mljekarstvo, 67(1), 3-16.

Bergillos-Meca, T., Cabrera-Vique, C., Artacho, R., Moreno-Montoro, M., NavarroAlarcón, M., Olalla, M., Giménez, R., Seiquer, I., Ruiz-López, M. 2015. Does Lactobacillus plantarum or ultrafiltration process improve $\mathrm{Ca}, \mathrm{Mg}, \mathrm{Zn}$ and $\mathrm{P}$ bioavailability from fermented goat's milk? Food Chemistry, 187, 314-321.

Bojanić Rašović, M., Mirecki, S., Nikolić, N., Vučinić, S., Ivanović I., Rašović, R. 2010. Mikrobiološki i hemijski kvalitet autohtonih sireva u Crnoj Gori. Prehrambena industrija-Mleko i mlečni proizvodi, 1-2, 127-133. 
BS (Bulgarian Standard) 1109-89. 1989. Milk and milk products. Methods for determination of moisture and dry matter.

BS (Bulgarian Standard) 1111-80. 1980. Milk and milk products. Determination of acidity.

BS (Bulgarian Standard) 15612:83. 1983. Dairy products. Sensorial assessment.

BS (Bulgarian Standard) 1671-89. 1989. Milk and dairy products: Methods for determination of fat content.

BS (Bulgarian Standard) 8274-82. 1982. Milk and dairy products. Methods for determination of $\mathrm{NaCl}$.

BS EN ISO 11290-1. 2017 Microbiology of the food chain - Horizontal method for the detection and enumeration of Listeria monocytogenes and of Listeria spp. - Part 1: Detection method.

BS EN ISO 6611. 2006. Milk and dairy products - Enumeration of colony-forming units of yeasts and/or molds - Colony-count technique at 25 degrees $\mathrm{C}$.

BS EN ISO 6888-1. 2005. Microbiology of food and animal feeding stuffs - Horizontal method for the enumeration of coagulase-positive staphylococci (Staphylococcus aureus and other species) - Part 1: Technique using Baird-Parker agar medium

BS EN ISO 8968-1. 2001. Milk - Determination of nitrogen content - Part 1: Kjeldahl method.

Buehler, A., Evanowski, R., Martin, N., Boor, K., Wiedmann, M. 2017. Internal transcribed spacer (ITS) sequencing reveals considerable fungal diversity in dairy products. Journal of Dairy Science, 100, 8814-8825.

Chen, S. Wang, J., Van Kessel, J., Ren, F., Zeng, S. 2010. Effect of somatic cell count in goat milk on yield, sensory quality, and fatty acid profile of semisoft cheese. Journal of Dairy Science, 93, 1345-1354.

Chipilev, N., Dascalov, H., Stoyanchev. T. 2016. Study on the prevalence of lipolytic yeasts and moulds in raw cow milk and white brined cheese. Bulgarian Journal of Veterinary Medicine, 19(2), 117-126.

Clark, S., García, M. 2017. A 100-year review: Advances in goat milk research. Journal of Dairy Science, 100(12), 10026-10044.

Da Silva, V., Da Costa, M. 2019. Influence of Processing on Rheological and Textural Characteristics of Goat and Sheep Milk Beverages and Methods of Analysis. In: Processing and Sustainability of Beverages, 373-412.

Dimitrova, T., Stoyocheva, S., Ivanova, S. 2020. Fatty acid profile and qualitative evaluationof the fat fraction in goat white brined cheese on the $45^{\text {th }}$ day of the of the ripening process. Scientific Papers. Series D. Animal Science. 58(1), 394-340.

Edgaryan, M., Panayotov, P. 2011. Technology of Cheeses' Types. (First Edition). Academic Publishing House of UFT, Plovdiv, pp. 292.

Hunt, K., Williams, J., Shafii, B., Hunt, M., Mehre, R., Ting, R., McGuire, M., McGuire M. 2013. Mastitis is associated with increased free fatty acids, somatic cell count, and interleukin-8 concentrations in human milk. Breastfeed Med, 8(1), 105-110.

IDF Standard 117B. 1997. Yogurt - Enumeration of characteristic microorganisms Colony-count technique at 37 degrees $\mathrm{C}$.

ISO 17410. 2019. Microbiology of the food chain - Horizontal method for the enumeration of psychrotrophic microorganisms.

ISO 4831. 2006 Microbiology of food and animal feeding stuffs - Horizontal method for the detection and enumeration of coliforms - Most probable number technique.

Kalevska, T., Uzunoska, Z., Stamatovska, V., Jankuloska, V. 2017. Quality of milk for the production of white brined cheese. Proceedings of University of Ruse, 56(10.2), 34-38. 
Lacanin, I., Mounier, J., Pawtowski, A., Dušková, M., Kameník, J., Karpíšková, `R. 2017. Assessment of the antifungal activity of Lactobacillus and Pediococcus spp. for use as bioprotective cultures in dairy products. World Journal of Microbiology and Biotechnology, 33, 188.

Petzer, I., Karzis, J., Donkin, E., Webb, E., Etter, E. 2017. Somatic cell count thresholds in composite and quarter milk samples as indicator of bovine intramammary infection status. Onderstepoort Journal of Veterinary Research, 84, a1269.

Regulation (EC) No 853/2004 of the European Parliament and of the Council of 29 April 2004 Laying down Specific Hygiene Rules for Food of Animal Origin.

Sandra, M., Dean, J., Pavle, S., Ljupco, A., Marija, R., Mirko, P. 2013. Microbiological properties and chemical composition of Macedonian traditional white brined cheese. Macedonian Veterinary Review, 36(1), 13-18.

Sharma, N., Singh, N., Bhadwal, M. 2011. Relationship of Somatic Cell Count and Mastitis: An Overview. Asian-Australasian Journal of Animal Sciences, 24(3), 429438.

Soliman Neveen, S., Salwa, A. 2011. Occurrence and identification of yeast species isolated from Egyptian Karish cheese. Academia Journal, 2(4), 59-64.

Sulejmani, E., Hayaloglu, A. 2017. Characterization of Macedonian white-brined cheese: Effect of raw or heat-treated caprine milk. International Journal of Dairy Technology, 70, 1-9.

Šuranská, H., Raspor, P., Uroić, K., Golić, N., Kos, B., Mihajlović, S., Begović, J., Šušković, J., Topisirović, L., Čadež, N. 2016. Characterisation of the yeast and mould biota in traditional white pickled cheeses by culture-dependent and independent molecular techniques. Folia Microbiologica, 61, 455-463.

Verruck, S., Dantas, A., Prudencio, E. 2019. Functionality of the components from goat's milk, recent advances for functional dairy products development and its implications on human health. Journal of Functional Foods, 52, 243-257.

Vianna, P., Mazal, G., Santos, M., Bolini, H., Gigante, M. 2008. Microbial and Sensory Changes Throughout the Ripening of Prato Cheese Made from Milk with Different Levels of Somatic Cells. Journal of Dairy Science, 91, 1743-1750. 